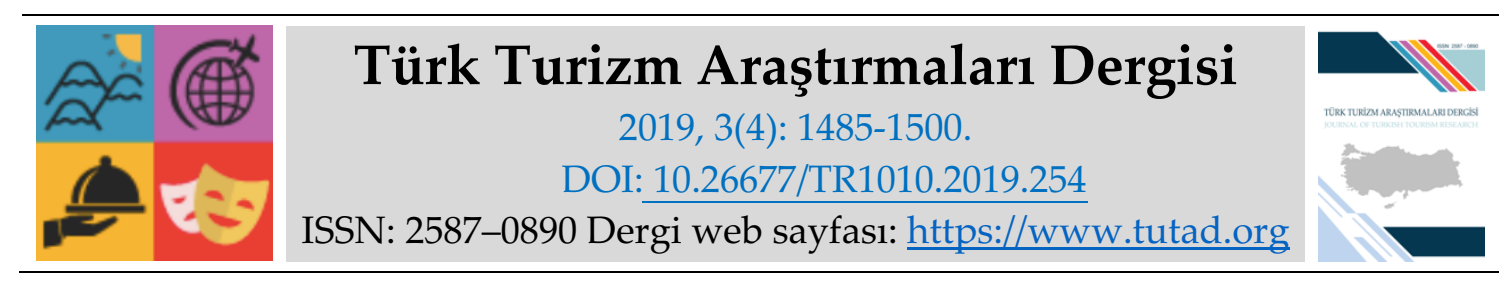

ARASTIRMA MAKALESI

\title{
Malatya İlinde Bulunan 3- 4 ve 5 Yıldızlı Otel Çalışanlarının İş-Aile Çatışma Düzeylerinin Ölçülmesi
}

Doç. Dr. Ahmet ÇAVUŞ, Atatürk Üniversitesi, Turizm Fakültesi, e-posta: ahmetcavus@atauni.edu.tr ORCID: https://orcid.org/0000-0002-7359-1273

Pınar AKER, Atatürk Üniversitesi Sosyal Bilimler Enstitüsü, e-posta: pnaraker@gmail.com

ORCID: https://orcid.org/0000-0003-3317-5109

Öz

İş-aile çatışmasını; iş ve aile arasındaki rollerin birbirleriyle uyumsuz olması sonucunda ortaya çıkan bir tür karşılıklı çatışma olarak tanımlamak mümkündür. İş-aile çatışması; zaman, gerilim ve davranış temelli iş-aile çatışması olarak 3 boyutta ele alınmaktadır. Bu çalışmada Malatya ilinde bulunan 3-4 ve 5 yıldızlı otel çalışanlarının iş-aile çatışma düzeylerinin ölçülmesi amaçlanmıştır. Çalışanların demografik özelliklerinin iş-aile çatışmasının alt boyutlarına göre anlamlı bir farklılık gösterip göstermediği tespit edilmeye çalışılmıştır. Anketler sonucunda elde edilen verilere güvenirlilik analizi ile beraber iki değişkenli gruplar için bağımsız örneklem Ttesti, ikiden fazla değişken olan gruplar için tek faktörlü varyans analizi uygulanmıştır. Ayrıca ikiden fazla gruplar için çoklu karşılaştırma testlerinden Tukey ve Bonferroni testinden yararlanılmıştır. Buna göre iş-aile çatışmasının boyutları, katılımcıların çocuk sahibi olmaları ve gelir düzeyleri arasında anlamlı farklılıklar olduğu tespit edilirken; cinsiyetleri, eşlerinin çalışma durumu, sektörde çalışma süreleri arasında anlamlı bir farklılık olmadığı tespit edilmiştir.

Anahtar Kelimeler: İ̧̧-Aile Çatışması, Turizm Sektörü, Malatya'daki Otel Çalışanları

Makale Gönderme Tarihi: 17.06.2019

Makale Kabul Tarihi: 06.10.2019

\section{Önerilen Atıf:}

Çavuş, A. ve Aker, P. (2019). Malatya İlinde Bulunan 3- 4 ve 5 Yıldızlı Otel Çalışanlarının İş-Aile Çatışma Düzeylerinin Ölçülmesi, Türk Turizm Araştırmaları Dergisi, 3(4): 1485-1500.

(c) 2019 Türk Turizm Araştırmaları Dergisi. 


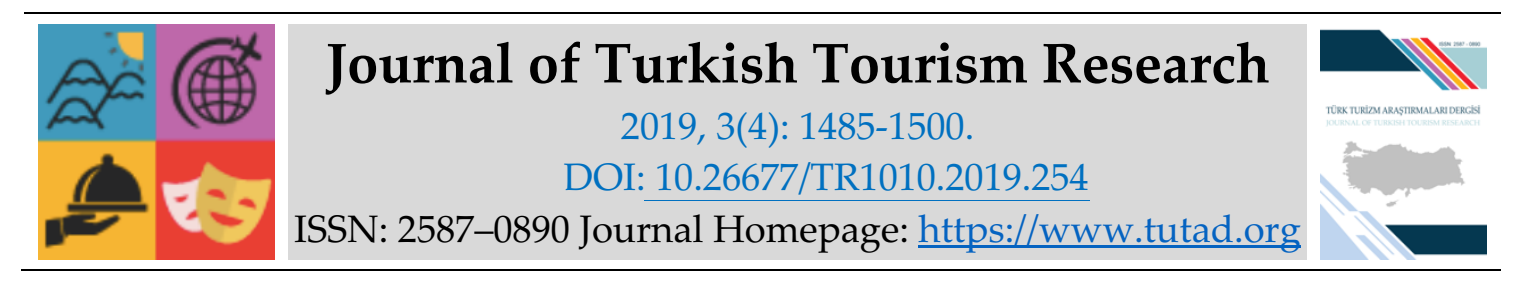

\title{
RESEARCH PAPER
}

\section{Measurement of Work-Family Conflict Levels of 3-4- and 5-Star Hotel Employees in Malatya}

Associate Prof. Dr. Ahmet ÇAVUŞ, Atatürk University, Faculty of Tourism, Erzurum, e-mail: ahmetcavus@atauni.edu.tr ORCID: https://orcid.org/0000-0002-7359-1273

Pınar AKER, Atatürk University, Social Sciences Institute, Erzurum, e-mail: pnaraker@gmail.com ORCID: https://orcid.org/0000-0003-3317-5109

\begin{abstract}
It is possible to define work-family conflict as a kind of mutual conflict which occurs as a result of the incompatibility of roles between work and family. Work-family conflict is examined in 3 dimensions; time-based, strain-based, and behavior-based work-family conflicts. In this study, it was aimed to measure the level of work-family conflict of 3-4- and 5-star hotel employees in Malatya. It was also aimed to find whether the levels of sub-dimensions of work-family conflict Show a significant difference according to demographic characteristics. The data obtained from the surveys, beside reliability analyses, were subjected to independent sample T-test for groups, with two variables a done factor variance analyses for groups with more than two variables. In addition, Tukey and Bonferroni tests were used for multiple comparison tests for more than two groups. According to the findings, there is a significant difference in work-family conflicts according to participants' having children, and income levels while there is no significant difference according to their gender, working status of spouses and duration of study.
\end{abstract}

Keywords: Work-Family Conflict, Tourism Sector, Hotel Employees in Malatya

Received: 17.06 .2019

Accepted: 06.10.2019

\section{Suggested Citation:}

Çavuş, A. and Aker, P. (2019). Measurement of Work-Family Conflict Levels of 3-4- and 5-Star Hotel Employees in Malatya, Journal of Turkish Tourism Research, 3(4): 1485-1500.

(C) 2019 Türk Turizm Araştırmaları Dergisi. 


\section{GİRIŞ}

Emek-yoğun bir sektör olan turizm, yirminci yüzyılın ikinci yarısından itibaren dünya ekonomisinde hızla gelişen ve büyüyen sektörlerden biri olmuştur (Köroğlu, 2011:246). Emekyoğun yapısından dolayı turizm sektöründe faaliyet gösteren işletmelerde diğer sektörlere nazaran işgücünün önemi çok daha fazladır. Çünkü çalışanların doyum düzeyleri ve psikolojik durumları, müşteri memnuniyetini hizmetin kalitesini doğrudan etkilemektedir (Karabacak, 2013:1). Bunun yanında esnek çalışma saatleri, personel devir hızının yüksek olması, bazı işletmelerin kış sezonlarında personel çıkarmaları ve izinlerin kısıtlı olması çalışanlar üzerinde stres yaratmaktadır. Bu durum kişilerin iş-aile çatışması yaşamasına, yaşam kalitesinde düşmeye, psikolojik rahatsızlıklara ve fiziksel sağlık sorunlarına neden olabilmektedir (Fındık, 2016:1). İşaile çatışması yaşayan bireyin örgütün işleyişine, gelişmesine ve geleceğine katkısı olmayacağı gibi (Kılıç, 2016:2), iş-aile yaşamı dengesi kurması da zorlaşmaktadır. Bireylerin iş-aile arasındaki dengeyi kurmaya çalışmaları kendileri kadar aileleri için de önem taşımaktadır. Aksi takdirde işaile çatışması boyutu kaçınılmazdır.

Bu çalışmada Malatya ilinde bulunan 3-4-5 yıldızlı otel çalışanlarının yaşadığı iş-aile çatışması düzeyi ölçülmeye çalışılmıştır. İlgili literatür taraması yapılmış, iş-aile çatışması boyutlarından olan iş-aile ve aile-iş çatışması konularına değinilmiştir. Malatya ilinde 3-4-5 yıldızlı otel çalışanlarına konuyla ilgili uygulanan anketler analiz edilip, yorumlanarak araştırma oluşturulmuştur.

\section{İŞ -AİLE ve AİLE-iş ÇATIŞMASI}

İş ve aile insan hayatında en önemli iki alandır. Aile kişinin ilk sosyalleştiği, hayatının temel ilgi ve gereksinimlerini tamamladığı ve sürdürdüğü en önemli toplumsal kurumlardan birisidir. İş ya da çalışma hayatı da bireyin ekonomik ve yaşamsal gereksinimlerini karşılamada ikinci önemli alandır. İş ve aile, bireyin hayatının iki önemli alanını oluştursa da, kişinin hayatı temelde bir bütündür ve tektir. İş ve aile rolleri birey hayatında iç içe geçmiş halde bulunur ve bu roller sürekli etkileşim halindedir. Birindeki olumlu ya da olumsuz durum diğerini çok kolaylıkla etkileyebilmekte ve duruma göre pozitif ve negatif etkide bulunabilmektedir (Arslan, 2012: 100). Genel olarak iş aile çatışması kavramı; iş ve aile arasındaki rollerin birbirleriyle uyumsuz olması sonucunda ortaya çıkan bir tür karşılıklı çatışma olarak tanımlanmıştır (Greenhaus ve Beutell, 1985: 77). Bir başka deyişle kişilerin yaşamdaki ebeveyn, eş, çalışan gibi farklı rollere sahip olması ve sahip olunan bu rolleri eş zamanlı yerine getiremediğinden dolayı yaşadığı çatışmalardır (Şentürk ve Bayraktar, 2018: 26).

Aile-iş çatışması ise bireyin ailesi ile ilgili sorumlulukların iş performansını engellemesi sonucu ortaya çıkan olumsuz durum olarak tanımlanabilir. Aile-iş çatışmasını ortaya çıkaran temel neden aile ve ailenin özellikleridir (Atabay, 2012: 19). Buna göre kişinin evli veya dul oluşu, çocuklarının sayısı ve yaşları, okul öncesi çağda çocukların varlığı, problemli çocuklar, bakımından sorumlu olunan yaşlıların varlığı, ailenin büyük olması, aile içinde yaşanan sorunlar aile-iş çatışmasına neden olabilmektedir (Çarıkçı, 2001: 37).

\section{ISS-AİLE ÇATIŞMASININ TÜRLERI}

İş-aile çatışması 3 türde ele alınmaktadır. Bunlar zaman temelli, gerilim temelli ve davranış temelli iş-aile türleridir. Zaman temelli iş-aile çatışması; bir rolün yerine getirilmesiyle ilgili zaman baskısının, diğer rolün taleplerini ve beklentilerini engellemesi durumunda oluşmaktadır. 
Bir başka ifadeyle iş veya aile rollerinden birinin yerine getirilmesi için ayrılan zamanın diğer rolün yerine getirilmesini zorlaştırması hatta olanaksız hale getirmesi ile ortaya çıkan bir çatışma şeklidir (Özdevecioğlu ve Doruk, 2009: 72). Zamansal çatışmanın işe ilişkin kaynakları; fazla çalışmanın sıklığı, çalışma programları, vardiyalı çalışma, vardiya düzensizliği ve çalışma programlarının esnek olmaması olarak belirtilmektedir. Bu nedenlerden kaynaklanan zaman baskıları diğer rolün talepleriyle uyuşmadığında zaman temelli iş-aile çatışması yaşanmaktadır. Aileden kaynaklanan zamansal çatışma ise, aile rolüne ayıracak zamanın çok daha fazla olması gereken durumlarda ortaya çıkmaktadır (Özen ve Uzun, 2005: 131).

İkinci iş-aile çatışması türü gerilim temelli iş-aile çatışmasıdır. Bazı kaynaklarda psikolojik sebepli çatışma olarak da geçen gerilim temelli iş-aile çatışması, bireylerin iş veya aile alanlarındaki üstlenilen rollerinden birisi ile alakalı olarak meydana gelen yorgunluk, gerilim, depresyon veya sinirlilik hallerinin, üstlenilmiş diğer rolüyle alakalı olarak, göstermesi gereken performansa etki etme durumudur (Shakhbazov, 2018: 11). Dolayısıyla gerginlik esaslı iş-aile çatışması kişinin iş ya da aile alanında üstlendiği rol nedeniyle hissettiği stres ve gerilimin diğer rolün gereklerinin yerine getirilmesini engellemesi ya da aksatması olarak ifade edilebilir (Atabay, 2012: 8). Gerilim temelli çatışmanın işe ilişkin nedenleri; iş rolündeki belirsizlik veya çatışma, aşırı rol yükü, lider desteğinin ve etkileşim kolaylığının düşük olması, fiziksel ve psikolojik iş talepleri, iletişimde stres ve işte beklenilen zihinsel konsantrasyon, işe bağlllık olmaktadır. Bir role yüksek düzeyde bağlılık, o role ayrılan zaman miktarını arttırmakta, ikinci rolün beklentilerinin karşılanmasını güçleştirmektedir (Çakır, 2011: 15).

İs-aile çatışmasında üçüncü ve son olarak davranış temelli çatışma türü bulunmaktadır. Hayatta her insanın farklı rolleri vardır. Bunların her birinin gerektirdiği davranışlar, tutumlar o role özgüdür. Kişi bir rolün gerektiği şekilde davranıp, diğer rolün gerektirdiği davranışı sağlayamıyor, uyum sorunu yaşıyorsa bu durum davranış esaslı çatışmaya sebep olacaktır (Kurtoğlu, 2017: 11). Bu bağlamda davranış temelli iş-aile çatışması, bir rolün gerektirdiği davranış biçiminin diğer bir roldeki davranış biçimiyle uyumsuz olması ya da uyumu güçleştirmesi durumu olarak tanımlanmaktadır (Yüksel, 2005: 303). Bir çalışanın iş ortamında başarılı iş performansı saldırgan, hırslı, çalışkan ve işe eğilimli olması gibi davranışsal özelliklerin gösterilmesiyle mümkün olabilir. Aile ortamında ise destekleyici, uyumlu ve aileye yönelimli olmak pozitif bir aile yaşamının gelişimi için zorunlu kabul edilmektedir. Bu karşıt davranışsal beklentiler bir alandan diğerine geçiş yaparken bireylerde gerginlik yaratarak roller arası çatışmaya neden olabilmektedir (Özen ve Uzun, 2005: 133).

\section{ARAŞTIRMANIN YÖNTEMI}

\section{Araştırmanın Önemi}

Turizm sektöründe yaşanan iş-aile çatışmasına yönelik ilgili literatür tarandığında çok sayıda çalışma olduğu görülmüştür. Örneğin; Koç ve Kızanlıklı (2017), Ankara' da bulunan 5 yıldızlı otel işletmelerindeki çalışanların iş-aile ve aile-iş yaşamı çatışma durumu ile iş performansı algısının, bireysel özelliklere göre farklılık gösterip göstermediğini ortaya koymayı amaçlamıştır. Aile-iş çatışması ile iş performansı algısı arasında negatif yönlü orta düzeyde; iş-aile çatışması ile performans algısı arasında da negatif yönlü zayıf bir ilişki tespit etmiştir. Harputluoğlu ve Polat (2017) İstanbul' da bulunan 4 ve 5 yıldızlı otel çalışanlarının işe tutkunluk ve iş-aile-iş çatışmasının işten ayrılma niyeti üzerindeki etkilerini incelemiştir. Araştırma sonuçlarında işe tutkunluğun işten ayrılma niyeti üzerinde olumsuz yönde etkisi olduğu sonucuna ulaşmıştır. Yurtseven (2008), turizm sektöründe faaliyet gösteren üç farklı seyahat acentasında çalışanların iş - aile 
çatışmasının alt boyutları olan zamana, strese ve davranışa dayalı iş - aile çatışmasının iş tatmini ve işten ayrılma niyeti üzerindeki etkilerini incelemiştir. İş- aile çatışmasının alt boyutları olan zamana ve strese dayalı iş - aile çatışmasının iş tatmini üzerinde olumsuz yönde etkisi olduğu sonucuna ulaşmıştır. Çakır (2011), Ankara' daki 4 ve 5 yıldızlı otel işletmelerindeki iş görenler ve yöneticiler ile iş-aile çatışmasına yönelik araştırma yapmış ve katılımcıların zaman temelli iş-aile çatışmasını, diğer iş-aile çatışması türlerine göre daha fazla yaşadıklarını belirlemiştir. Karabacak (2013), İstanbul'daki 5 yıldızlı otel çalışanlarının iş stresi, algılanan sosyal destek ve iş-aile yaşam çatışmasının iş ve yaşam doyumu üzerindeki etkilerini incelemeyi amaçlamıştır. Diker (2010), Nevşehir'de bulunan 5 yıldızlı otel çalışanlarının işe bağlılığı, iş-aile çatışması ve faktörleri üzerindeki etkisini ölçmeyi amaçlamıştır. İşe bağlılığın iş-aile yaşam çatışması üzerinde herhangi bir etkisinin olmadığı ve iki değişken arasında oldukça zayıf bir ilişkinin bulunduğunu belirlemiştir. İnal (2016), çalışmasında Nevşehir'de bulunan otel işletmelerindeki iş görenlerin işaile çatışmasının örgütsel bağlılık ve işten ayrılma niyeti üzerine etkisini ortaya koymayı amaçlamıştır. İş-aile çatışmasının örgütsel bağlılık ve işten ayrılma niyeti üzerine etkisi olduğunu saptamıştır. Işık (2015), çalışmasında Erzurum'da bulunan konaklama işletmesindeki çalışanların duygusal emek ve iş-aile çatışması ilişkisini incelemiştir. Çalışmasında iş görenlerin duygusal emek düzeyleri ile iş-aile çatışması düzeyleri arasında pozitif yönde anlamlı bir ilişki olduğunu tespit etmiştir.

Yapılan araştırmalar sonucunda Malatya ilinde iş-aile çatışmasını ölçmeye yönelik bir çalışmanın yapılmamış olması araştırmanın önemini vurguladığı gibi çıkış noktasını da oluşturmaktadır.

\section{Araştırmanın Amacı}

$\mathrm{Bu}$ araştırmanın amacı Malatya ilinde bulunan turizm işletme belgeli 3-4-5 yıldızlı otel çalışanlarının iş-aile yaşamı arasındaki çatışma düzeyini ölçmeye yöneliktir. Bunun yanında çalışanların demografik özelliklerine göre iş-aile çatışması arasında anlamlı bir fark olup olmadığı da araştırılmıştır.

Araştırmada cevabı aranacak sorular;

- İş-aile çatışmasının alt boyutları arasında anlamlı farklılık var mıdır?

- Katılımcıların yaşadığı iş-aile çatışması katılımcıların cinsiyetlerine, eşlerinin çalışma durumuna, çocuk sahibi olmalarına, gelirlerine ve turizm sektöründe çalışma sürelerine göre anlamlı farklılık göstermekte midir?

\section{Araştırmanın Evreni ve Örneklemi}

Araştırma Malatya ilinde bulunan turizm işletme belgeli konaklama işletmelerine yönelik olduğu için öncelikle turizm işletme belgeli otel sayısı belirlenmiştir. Konaklama işletmelerinden üç tanesi 5 yıldızlı, üç tanesi 4 yıldızlı ve altı tanesi 3 yıldızlı olmak üzere toplamda 12 adettir. Bu işletmelerde çalışan toplam kişi sayısı yani evren hacmi 264 olarak belirlenmiştir. Evren büyüklügüne göre örneklem hesaplanmakta olup Sosyal Bilimlerde genel kabul olan \%95 güven aralığında evren hacmi 270 ise örneklem hacmi 159, evren hacmi 260 ise örneklem hacmi 157 olmaktadır (Ural ve Kılıç, 2018: 43). Araştırma kapsamında belirlenen evren hacmi 264 kişi olduğundan örneklem hacmi 159 olarak belirlenmiştir. Örneklem sayısının belirlenmesinin ardından konaklama işletmelerinin her birine gidilerek çalışmanın kapsamı anlatılmış ve çalışanların anket doldurmaları istenmiştir. İşletmelerden üç tanesi 5 yıldızlı, iki tanesi 4 yıldızlı ve dört tanesi 3 yıldızlı olmak üzere toplamda 9 tanesi anket doldurmayı kabul etmiştir. 
Konaklama işletmelerinden bazıları hemen anketi doldurup vermiş, bazılarına ise anket formları bırakılmış, sonrasında randevu alınarak anketler toplanmıştır. Toplamda 180 adet anket dağıtılmış ve bunlardan 165 tanesi doğru ve eksiksiz doldurulduğu için değerlendirilmeye alınmıştır.

\section{Veri Toplama Aracı ve Yöntemi}

Çalışanların iş-aile çatışması düzeylerini ölçmek için, Camp vd., (2006) tarafından yapılan araştırmada kullanılan ve farklı kaynaklardan uyarlanmış, 26 maddeden oluşan iş-aile çatışması ölçeğinden yararlanılmıştır. Ölçeğin Türkçe'ye uyarlaması, dil bilimcileri ve uzman akademisyenlerin görüş ve yardımıyla yapılmıştır. Ölçeğin Türkçe'ye uyarlaması sırasında, bazı maddeler ikiye ayrılmış ve bütün ifadeler 33 soruda toplanmıştır. Ölçek aynı zamanda Yurtseven (2008) tarafından Türkçe 'ye uyarlanarak turizm sektöründe de uygulanmıştır (Çakır, 2011: 32). Bu kapsamda Çakır (2011) ‘n çalışmasındaki anket ölçeği örnek alınmış ve uygulanmıştır. Ancak Çakır'ın yapmış olduğu çalışma 4 ve 5 yıldızlı otellerdeki çalışan ve yöneticilere yönelik olduğundan anket ölçeğinin demografik özellikleri kısmında bazı sorularda düzenlemeler yapılmıştır. Toplamda 33 sorudan oluşan anket ölçeğinin 1-10 arasındaki sorular zaman temelli çatışmayı ölçmeye yönelik, 11-24 arasındaki sorular gerilim temelli çatışmayı ölçmeye yönelik, 25-27 arasındaki sorular davranış temelli çatışmayı ölçmeye yönelik ve 28-33 arasındaki sorular aile-iş çatışmasını ölçmeye yönelik sorulardır.

\section{Verilerin Analizi}

Araştırmada anket yöntemi ile toplanan verilerin analizi SPSS (Statistical Package for Social Sciences) 22.0 programı ile yapılmıştır. Öncelikle veriler SPSS programına girilmiştir. Bunun yanında araştırma kapsamında yer alan özelliklerin her bir ifadesi için; frekansları, yüzdelik dağılımları, ortalaması, standart sapması hesaplanmıştır. Ayrıca katılımcıların iş-aile çatışmasının alt boyutlarına yönelik demografik özelliklerinden iki değişkenli (cinsiyet, eşlerinin çalışma durumu,) gruplar için bağımsız örneklem T-test (Independent Sample T-Test), ikiden fazla değişken (gelir düzeyleri, çocuklarının sayısı, sektörde çalışılan süre) olan gruplar için tek faktörlü varyans analizi (One-Way ANOVA) kullanılmıştır. Ayrıca ikiden fazla gruplar için çoklu karşılaştırma testlerinden Tukey ve Bonferroni testinden yararlanılmıştır. Bunun dışında araştırmanın güvenirlik analizi olarak Cronbach's Alpha'dan yararlanılmış ve iş-aile çatışmasının alt boyutlarının faktör analizi yapılmıştır.

\section{Faktör ve Güvenirlilik Analizi}

Faktör analizi, gözlemlenen çok sayıdaki değişken içerisinden gruplandırılmış temel değişkenler ya da faktörler tanımlayarak değişken sayısını azaltmak amacı ile yapılmaktadır. Tanımlanan her bir faktör, değişkenler arasındaki ilişkinin ölçülmesi sonucu aynı özelliği ölçen birbiri ile ilişkili değişken setinden oluşmaktadır (Ural ve Kılıç, 2018: 263).

Faktör analizi sonucunda boyutlardaki sorularda kayma veya yer değiştirme yaşanmadığından orijinal ölçek boyutlarına bağlı kalınmıştır. Böylece zaman temelli, gerilim temelli, davranış temelli ve aile-iş temelli iş-aile çatışmasını oluşturan 4 faktörün toplam varyansın \%67,830'unu oluşturduğu ortaya çıkmıştır. Bu kapsamda zaman temelli iş-aile çatışması faktörü toplam varyansın \%26,144'ünü, gerilim temelli iş-aile çatışması faktörü toplam varyansın $\% 13,952$ 'sini, 
davranış temelli iş-aile çatışması faktörü toplam varyansın \%13,912'sini ve aile-iş temelli iş-aile çatışması faktörü toplam varyansın $\% 13,822$ 'sini oluşturmaktadır.

Güvenirlilik analizi; herhangi bir konuda örneklemi oluşturan birimler üzerinden veri toplamak amacı ile geliştirilen ölçme aracını oluşturan ifadelerin (yargı, önerme, soru vb.) kendi aralarında tutarlılık gösterip göstermediği test etmek amacı ile kullanılmaktadır. Diğer bir deyişle, deneklerin ölçme aracını oluşturan ifadelere yaklaşımlarından (cevaplarından) hareket ile deneklere yöneltilen ifadelerin tümünün aynı konuyu ölçüp ölçmediği test edilmektedir (Ural ve Kılıç, 2018: 268).

Tablo 1. İş-Aile Çatışması Alt Boyutlarının Güvenirlik Katsayıları

\begin{tabular}{|l|c|}
\hline Faktörler & Güvenirlik Katsayısı $(\boldsymbol{\alpha})$ \\
\hline 1. Faktör Zaman Temelli & 0,84 \\
\hline 2. Faktör Gerilim Temelli & 0,80 \\
\hline 3. Faktör Davranış Temelli & 0,84 \\
\hline 4. Faktör Aile-iş Temelli & 0,89 \\
\hline
\end{tabular}

Araştırmada güvenirlik analizinde Alpha(Cronbach's Alpha) katsayısı dikkate alınmış ve çatışma türlerinin tümü için Alpha katsayısı $\alpha=0.882$ olarak bulunmuştur. Ayrıca Tablo 1'den de görüleceği üzere zaman temelli iş-aile çatışması $\alpha=0,84$; gerilim temelli iş-aile çatışması $\alpha=0,80$; davranış temelli iş-aile çatışması $\alpha=0,84$ ve aile-iş temelli iş-aile çatışması $\alpha=0,89$ güven aralığındadır. Bulunan sonuçlar kapsamında ölçeğin güvenilir olduğu söylenebilir (Ural ve Kılıç, 2018: 268).

\section{BULGULAR VE YORUMLAR}

\section{Katılımcıların Demografik Özellikleri}

Bu bölümde ankete katılan otel çalışanlarının cinsiyet, medeni durum, yaş, eğitim durumu, çalışanların eşlerinin çalışma durumu, sahip olunan çocuk sayısı, aylık gelirleri, çalıştıkları departman, işletmede çalıştıkları süre ve sektörde çalıştıkları süre ile ilgili frekans analizi yapılmış ve çalışanların nitelikleri belirlenmeye çalışılmıştır.

Araştırmaya katılanların \%48,5'i kadınlardan, \%51,5'i erkeklerden, \%48,5'i evlilerden, \%49,7'si bekârlardan, \%27,9'u 21-25 yaş grubundan; \%24,2' sinin 31-35 yaş grubundan ve \%21,8'inin 26-30 yaş grubundan oluşmaktadır. Eğitim düzeyleri incelendiğinde $\% 35,2$ 'sinin lise, $\% 23$ ön lisans ve \%22,4'ünün lisans mezunu olduğu görülür (Tablo 2).

Araştırmaya katılan evli çalışanlardan \%28,5'inin eşlerinin çalıştığ ve \%23'ünün 2 tane çocuk sahibi olduğu saptanmıştır. Katılımcıların \%58,8'inin 1603 TL (2018 yılı asgari ücreti) ve altında, \%40'ının 1604-2499 TL arasında aylık gelirinin olduğu; \%33,3'ünün ön büro, \%30,9'unun yiyecekiçecek ve \%26,7'sinin kat hizmetleri departmanında çalıştığı, \%41,8'inin 1 yıldan az ve \%35,8'inin 1-4 yıl arasında işletmede çalıştığı anlaşılmaktadır. Ayrıca \%25,5'inin 1 yıldan az ve yine aynı oranla \%25,5'inin 1-4 yıl arası turizm sektöründe çalıştığı tespit edilmiştir (Tablo 2). 
Tablo 2. Katılımcıların Demografik Özellikleri

\begin{tabular}{cccccc}
\hline & \multicolumn{6}{c}{ Değişkenler } & \\
\hline Cinsiyet & $\mathbf{( N )}$ & $\mathbf{( \% )}$ & $\begin{array}{c}\text { Eşlerin Çalışma } \\
\text { Durumu }\end{array}$ & $\mathbf{( N )}$ & $\mathbf{( \% )}$ \\
\hline Kadın & 80 & 48,5 & Çalışıor & 47 & 28,5 \\
\hline Erkek & 85 & 51,5 & Çalışmıyor & 36 & 21,8 \\
\hline
\end{tabular}

\begin{tabular}{cccccc}
\hline Eğitim Düzeyi & $\mathbf{( N )}$ & $\mathbf{( \% )}$ & Yaş & $\mathbf{( N )}$ & $\mathbf{( \% )}$ \\
\hline İlkokul & 12 & 7,3 & 20 yaş ve altı & 4 & 2,4 \\
\hline Ortaokul & 18 & 10,9 & $21-25$ yaş & 46 & 27,9 \\
\hline Lise & 58 & 35,2 & $26-30$ yaş & 36 & 21,8 \\
\hline Ön lisans & 38 & 23,0 & $31-35$ yaş & 40 & 24,2 \\
\hline Lisans & 37 & 22,4 & $36-40$ yaş & 28 & 17,0 \\
\hline $\begin{array}{c}\text { Yüksek lisans- } \\
\text { Doktora }\end{array}$ & 2 & 1,2 & 41 yaş ve üstü & 11 & 6,7 \\
\hline
\end{tabular}

\begin{tabular}{cccccc}
\hline Medeni Durum & $\mathbf{( N )}$ & $\mathbf{( \% )}$ & Gelir Durumu & $\mathbf{( N )}$ & $\mathbf{( \% )}$ \\
\hline Bekâr & 80 & 48,5 & $\begin{array}{c}1603 \text { TL(Asgari Ücret) } \\
\text { ve Daha Az }\end{array}$ & 97 & 58,8 \\
& & \multicolumn{5}{c}{$\begin{array}{c}\text { 1604 TL }-2.499 \mathrm{TL} \\
\text { Evli }\end{array}$} & 82 & 49,7 & 66 & 40,0 \\
\hline $\begin{array}{c}\text { Diğer } \\
\text { (Boşanmış, Dul) }\end{array}$ & 3 & 1,8 & $2.500-3.999 \mathrm{TL}$ & 2 & 1,2 \\
\hline
\end{tabular}

\begin{tabular}{cccccc}
\hline $\begin{array}{c}\text { Çocuk Sahibi } \\
\text { Olma Durumu }\end{array}$ & $\mathbf{( N )}$ & $\mathbf{( \% )}$ & $\begin{array}{c}\text { İşletmede Çalışılan } \\
\text { Süre }\end{array}$ & $\mathbf{( N )}$ & $\mathbf{( \% )}$ \\
\hline Yok & 11 & 6,7 & 1 yll ve daha az & 69 & 41,8 \\
\hline 1 tane & 23 & 13,9 & $2-4$ yıl & 59 & 35,8 \\
\hline 2 tane & 38 & 23,0 & $5-7$ yıl & 31 & 18,8 \\
\hline 3 tane & 12 & 7,3 & $8-10$ yıl & 3 & 1,8 \\
\hline & & & 11 yıl ve daha çok & 3 & 1,8 \\
\hline
\end{tabular}

\begin{tabular}{cccccc}
\hline $\begin{array}{c}\text { Çalışılan } \\
\text { Departman }\end{array}$ & $\mathbf{( N )}$ & $\mathbf{( \% )}$ & $\begin{array}{c}\text { Sektörde Çalışılan } \\
\text { Süre }\end{array}$ & $\mathbf{( N )}$ & $\mathbf{( \% )}$ \\
\hline Ön büro & 55 & 33,3 & 1 yıl ve daha az & 42 & 25,5 \\
\hline Yiyecek-İçecek & 51 & 30,9 & 1 yıl-3 yılldan az & 42 & 25,5 \\
\hline Kat Hizmetleri & 44 & 26,7 & 3 yıl-5 yıldan az & 32 & 19,4 \\
\hline Halkla İlişkiler & 5 & 3,0 & 5 yıl-7 yıldan az & 18 & 10,9 \\
\hline Muhasebe & 2 & 1,2 & 8 yıl-10 yıldan az & 23 & 13,9 \\
\hline Dï̆ger (Mutfak) & 8 & 4,8 & 11 yıl-13 yıldan az & 4 & 2,4 \\
\hline & & & 13 yıl-15 yıldan az & 1 & 0,6 \\
\cline { 3 - 5 } & & & 15 yıl-17 yıldan az & 3 & 1,8 \\
\hline
\end{tabular}




\section{Araştırmanın Hipotezleri}

Bu kısımda araştırma kapsamında yapılan iş-aile çatışması anketi sonuçlarında katılımcıların işaile çatışmasının demografik özelliklerine göre anlamlı farklılık gösterip gösterilmediği hipotezler üzerinden değerlendirilmiştir.

Araştırmanın hipotezleri;

H1. İş-aile çatışmasının alt boyutları arasında anlamlı farklııı vardır.

H2. Katılımcıların yaşadığı iş-aile çatışması katılımcıların cinsiyetlerine göre anlamlı farklılık göstermektedir.

H3. Katılımcıların yaşadıkları iş-aile çatışması, katılımcıların eşlerinin çalışma durumuna göre anlamlı farklılık göstermektedir.

H4. Katılımcıların yaşadıkları iş-aile çatışması, katılımcıların çocuk sahibi olma durumuna göre anlamlı farklılık göstermektedir.

H5. Katılımcıların yaşadıkları iş-aile çatışması, katılımcıların gelir düzeyine göre anlamlı farklılık göstermektedir.

H6. Katılımcıların yaşadıkları iş-aile çatışması, katılımcıların turizm sektöründe çalışma sürelerine göre anlamlı farklllık göstermektedir.

\section{Hipotezlerin Test Edilmesi}

Anket içerisinde yer alan iş-aile çatışma boyutlarının birbirleri ile anlamlı farklılık gösterip göstermediği belirlemek için Bonferroni, en fazla çatışmanın hangi boyutta yaşandı̆̆ını belirlemek amacıyla ise ortalamalar üzerinden yorumlama yapılmıştır.

Tablo 3. İş-Aile Çatışmasının Alt Boyutlarının Karşılaştırılması

\begin{tabular}{|l|c|c|c|}
\hline İş-Aile Çatışması Alt Boyutları & $\bar{X}$ & Std. Sapma & \multirow{2}{*}{$\mathbf{p}$} \\
\hline Zaman Temelli Çatışma & 2,87 & 1,09 & \multirow{2}{*}{$\mathbf{0 . 0 0 0}^{*}$} \\
\cline { 1 - 3 } Gerilim Temelli Çatışma & 2,58 & 1,00 & \\
\cline { 1 - 3 } Davranış Temelli Çatışma & 2,37 & 1,00 & \\
\hline Aile-iş Temelli Çatışma & 2,03 & 0,88 & \\
\hline
\end{tabular}

Tablo 3'den anlaşılacağı üzere iş-aile çatışmasının alt boyutları olan zaman, gerilim, davranış ve aile-iş temelli iş aile çatışması arasında anlamlı bir farklılık olduğu görülmektedir $(p<0,05)$. Buna göre;

"H1. İş-aile çatışmasının alt boyutları arasında anlamlı farklılık vardır." hipotezi kabul edilmiştir.

İş-aile çatışması boyutlarının çoklu karşılaştırılmasına yönelik Bonferroni testi yapılmış ve alt boyutlar arasında anlamlı farklılık bulunmuştur. Söz konusu testin sonunda en olumsuz cevap zaman temelli çatışma boyutunda görülmüştür. Bunu sırasıyla gerilim, davranış ve aile-iş temelli çatışma türleri takip etmektedir. İş-aile çatışması boyutlarının ortalaması incelendiğinde; en fazla çatışmanın yine zaman temelli çatışma boyutunda $(\bar{x}=2,87)$ olduğu belirtilmelidir. Bunu gerilim temelli çatışma $(\bar{x}=2,58)$, davranış temelli çatışma $(\bar{x}=2,37)$ ve aile-iş temelli çatışma $(\bar{x}=2,03)$ takip etmektedir. Turizm, yoğun ve vardiyalı çalışmanın olduğu, insan emeğine dayalı hizmetin yer 
aldığı bir sektördür. Dolasıyla bu sektörde çalışan bireyler yeri geldiğinde kendilerinden ödün vererek işlerine yoğunlaşmakta ve müşteri memnuniyetini üst seviyede tutmak zorunda kalmaktadır. Bu durum çalışan bireylerin kendilerine ve ailelerine fazla zaman ayırmamasına neden olmaktadır. Kısıtlı bir kaynak olan zamanın çoğunu işine ayıran birey, ailesine ayıracağ zamanı bulamadığından, bu durumun iş-aile çatışmasına zemin hazırlayacağı düşünülmektedir (Baykal, 2014:15).

Tablo 4. Katılımcıların İş-Aile Çatışmasının Cinsiyetlerine Göre Karşılaştırılması

\begin{tabular}{|c|c|c|c|c|c|}
\hline Boyutlar & Cinsiyet & $\mathbf{N}$ & $\bar{X}$ & Std. Sapma & $\mathrm{p}$ \\
\hline \multirow{2}{*}{ Zaman Temelli } & Kadın & 80 & 2,98 & 1,03 & 0,146 \\
\hline & Erkek & 85 & 2,77 & 1,14 & \\
\hline \multirow[b]{2}{*}{ Gerilim Temelli } & Kadın & 80 & 2,75 & 0,97 & 0,938 \\
\hline & Erkek & 85 & 2,41 & 1,01 & \\
\hline \multirow[b]{2}{*}{ Davranış Temelli } & Kadın & 80 & 2,57 & 1,02 & 0,831 \\
\hline & Erkek & 85 & 2.19 & 0,95 & \\
\hline \multirow{2}{*}{ Aile-İş Temelli } & Kadın & 80 & 2.18 & 0,97 & $0,036^{*}$ \\
\hline & Erkek & 85 & 1,88 & 0,77 & \\
\hline
\end{tabular}

Tablo 4'de katılımcıların yaşadığı iş-aile çatışmasının katılımcıların cinsiyetlerine göre anlamlı farklılık gösterip göstermediğini belirleyebilmek amacıyla bağımsız örneklem T-test uygulanmış ve yalnızca aile-iş temelli iş-aile çatışması boyutunda anlamlı bir farklılık $(p<0,05)$ olduğu tespit edilmiştir. Tüm boyutlarda anlamlı farklılık görülmediğinden;

“H2. Katılımcıların yaşadığı iş-aile çatışması katılımcıların cinsiyetlerine göre anlamlı farklılık göstermektedir." hipotez kabul edilmemiştir.

Sonuçlar incelendiğinde, zaman temelli (kadın $\bar{x}=2,98$ - erkek $\bar{x}=2,77$ ), gerilim temelli (kadın $\bar{x}=2,75$ - erkek $\bar{x}=2,41$ ), davranış temelli (kadın $\bar{x}=2,57$ - erkek $\bar{x}=2,19$ ) ve aile-iş temelli iş-aile çatışmasında ( $k$ dıdı $\bar{x}=2,18$ - erkek $\bar{x}=1,88$ ) kadınların erkeklere göre daha fazla etkilendikleri görülmektedir. Analiz sonucunda aile-iş temelli çatışma türünde kadınların erkeklere oranla daha fazla iş-aile çatışması yaşadığı görülmektedir. Bunun önemli nedenlerinden biri de, kadının evde geleneksel rolleri, işte modern iş koşullarına uygun rolleri yerine getirmesinin beklenmesidir. Dolayısıyla bu durum kadının özellikle aile ve iş hayatında erkeğe oranla daha fazla çatışma yaşadığı durumunu ortaya çıkarmaktadır (Arslan, 2012:100).

Tablo 5. Katılımcıların İş-Aile Çatışmasının Eşlerinin Çalışma Durumuna Göre Karşılaştırılması

\begin{tabular}{lccccc}
\hline \multicolumn{1}{c}{ Boyutlar } & $\begin{array}{c}\text { Eşlerinin Çalışma } \\
\text { Durumu }\end{array}$ & $\mathbf{N}$ & $\overline{\boldsymbol{X}}$ & Std. Sapma & $\mathbf{p}$ \\
\hline \multirow{2}{*}{ Zaman Temelli } & Çalışıyor & 47 & 2,91 & 0,96 & $\mathbf{0 , 0 2 3 ^ { * }}$ \\
& Çalışmıyor & 36 & 2,77 & 1,24 & \\
\hline \multirow{2}{*}{ Gerilim Temelli } & Çalışıyor & 47 & 2,62 & 0,95 & 0,191 \\
& Çalışmıyor & 36 & 2,53 & 1,15 & \\
Davranış Temelli & Çalışıyor & 47 & 2,41 & 0,96 & 0,659 \\
\hline \multirow{2}{*}{ Aile-İş Temelli } & Çalışmyor & 36 & 2,28 & 1,03 & \\
& Çalışıyor & 47 & 2,14 & 0,94 & 0,826 \\
& Çalışmiyor & 36 & 2,00 & 0,91 &
\end{tabular}


Tablo 5'de iş-aile çatışmasının alt boyutu olan zaman temelli çatışmanın, katılımcıların eşlerinin çalışma durumuna göre anlamlı farklılık gösterip göstermediğini belirleyebilmek amacıyla bağımsız örneklem T-test uygulanmış ve yalnızca zaman temelli iş-aile çatışması boyutunda anlamlı bir farklılık $(\mathrm{p}<0,05)$ olduğu tespit edilmiştir. Tüm boyutlarda anlamlı farklılık olmadığından;

“H3. İş-aile çatışmasının alt boyutu olan zaman temelli çatışma, katılımcıların eşlerinin çalışma durumuna göre anlamlı farklılık göstermektedir." hipotezi kabul edilmemiştir.

Katılımcıların cevaplarının ortalaması incelendiğinde zaman temelli iş-aile çatışmasını $(\bar{x}=2,91)$, gerilim temelli iş-aile çatışmasını $(\bar{x}=2,62)$, davranış temelli iş-aile çatışmasını eşleri çalışanlar $(\bar{x}=2,41)$ yaşamaktayken; aile-iş temelli iş-aile çatışmasını da eşleri çalışmayanlar $(\bar{x}=2,14)$ yaşamaktadır. İş ve ailenin etkileşiminden dolayı ortaya çıan problemler en fazla iki eşin de ücretli birer işte çalıştıkları aile tipinde yaşanmaktadır. Çift gelirli ailelerde üç farklı işin bir araya getirilmesi gerekmektedir: eşlerin ücretli işleri ve ev işleri. Dolayısıyla, bu aile tipinde iş-aile çatışmasına neden olan temel özelliklerin hepsi yer almaktadır (Çarıkçı, 2001: 89).

Tablo 6. Katılımcıların İş-Aile Çatışmasının Çocuk Sahibi Olma Durumlarına Göre Karşılaştırılması

\begin{tabular}{|c|c|c|c|c|c|}
\hline Boyutlar & $\begin{array}{c}\text { Sahip Olunan Çocuk } \\
\text { Sayısı }\end{array}$ & $\mathbf{N}$ & $\bar{X}$ & Std. S. & $\mathrm{p}$ \\
\hline & Çocuğu yok & 11 & 2,80 & 1,18 & \\
\hline \multirow[t]{3}{*}{ Zaman Temelli } & 1 tane & 23 & 3,16 & 1,18 & $0,050^{*}$ \\
\hline & 2 tane & 38 & 2,91 & 1,00 & \\
\hline & 3 tane & 12 & 2,10 & 0,78 & \\
\hline \multirow{4}{*}{ Gerilim Temelli } & Çocuğu yok & 11 & 2,60 & 1,01 & \\
\hline & 1 tane & 23 & 2,95 & 1,16 & $0,017^{*}$ \\
\hline & 2 tane & 38 & 2,62 & 0,92 & \\
\hline & 3 tane & 12 & 1,79 & 0,76 & \\
\hline \multirow{4}{*}{ Davranış Temelli } & Çocuğu yok & 11 & 2,33 & 1,03 & \\
\hline & 1 tane & 23 & 2,56 & 1,09 & $0,043^{*}$ \\
\hline & 2 tane & 38 & 2,47 & 0,83 & \\
\hline & 3 tane & 12 & 1,63 & 0,94 & \\
\hline \multirow{4}{*}{ Aile-İş Temelli } & Çocuğu yok & 11 & 1,62 & 0,60 & \\
\hline & 1 tane & 23 & 2,21 & 0,94 & $0,036^{*}$ \\
\hline & 2 tane & 38 & 2,25 & 0,94 & \\
\hline & 3 tane & 12 & 1,55 & 0,82 & \\
\hline
\end{tabular}

Tablo 'da iş-aile çatışması alt boyutları olan zaman temelli, gerilim temelli, davranış temelli ve aile-iş temelli iş aile çatışmasının, katılımcıların çocuk sahibi olma durumlarına göre $(p<0,05)$ anlamlı bir farklılık gösterdiğini görülmektedir. Buna göre;

"H4. Katılımcıların yaşadıkları iş-aile çatışması, katılımcıların çocuk sahibi olma durumlarına göre anlamlı farklılık göstermektedir." hipotezi kabul edilmiştir.

Katılımcların cevaplarının ortalaması incelendiğinde zaman temelli iş-aile çatışmasını $(\bar{x}=3,16)$, gerilim temelli iş-aile çatışmasını $(\bar{x}=2,95)$ ve davranış temelli iş-aile çatışmasını $(\bar{x}=2,56) 1$ tane çocuğu olanlar yaşamaktayken; aile-iş temelli iş-aile çatışmasını $(\bar{x}=2,25)$ en fazla yaşayan grubunun 2 tane çocuk sahibi olan grup olduğu görülmektedir. 
Tablo 7. Katılımcıların İş-Aile Çatışmasının Gelir Düzeylerine Göre Karşılaştırılması

\begin{tabular}{|c|c|c|c|c|c|}
\hline Boyutlar & Gelir Düzeyi & $\mathbf{N}$ & $\bar{X}$ & $\begin{array}{c}\text { Std. } \\
\text { Sapma }\end{array}$ & $\mathrm{p}$ \\
\hline \multirow{3}{*}{ Zaman Temelli } & 1603 TL (Asgari Ücret) ve altı & 97 & 3,18 & 0,96 & \multirow{3}{*}{$0,000^{*}$} \\
\hline & $1604-2499 \mathrm{TL}$ & 66 & 2,45 & 1,13 & \\
\hline & 2500-3999 TL & 2 & 2,15 & 1,20 & \\
\hline \multirow{3}{*}{ Gerilim Temelli } & 1603 TL (Asgari Ücret) ve altı & 97 & 2,87 & 0,97 & \multirow{3}{*}{$0,000^{*}$} \\
\hline & $1604-2499 \mathrm{TL}$ & 66 & 2,16 & 0,91 & \\
\hline & 2500-3999 TL & 2 & 2,07 & 0,80 & \\
\hline \multirow{3}{*}{ Davranış Temelli } & 1603 TL (Asgari Ücret) ve altı & 97 & 2,56 & 1,02 & \multirow{3}{*}{$0,022^{*}$} \\
\hline & $1604-2499 \mathrm{TL}$ & 66 & 2,12 & 0,93 & \\
\hline & 2500-3999 TL & 2 & 2,16 & 0,70 & \\
\hline \multirow{3}{*}{ Aile-İş Temelli } & 1603 TL (Asgari Ücret) ve altı & 97 & 2,14 & 0,92 & \\
\hline & 1604-2499 TL & 66 & 1,86 & 0,81 & \\
\hline & $2500-3999 \mathrm{TL}$ & 2 & 1,66 & 0,70 & $0,012^{*}$ \\
\hline
\end{tabular}

Tablo 7'de katılımcıların iş-aile çatışmasının gelir düzeylerine göre anlamlı farklılık gösterip göstermediğini belirleyebilmek amacıyla yapılan tek faktörlü varyans analizinde zaman temelli, gerilim temelli, davranış temelli iş-aile boyutlarında anlamlı farklılık $(\mathrm{p}<0,05)$ olduğu tespit edilmiştir

"H5. Katılımcıların yaşadıkları iş-aile çatışması, katılımcıların gelir düzeylerine göre anlamlı farklılık göstermektedir." hipotezi kabul edilmiştir.

Katılımcıların cevaplarının ortalaması incelendiğinde zaman temelli iş-aile çatışmasını $(\bar{x}=3,18)$, gerilim temelli iş-aile çatışmasını $(\bar{x}=2,87)$, davranış temelli iş-aile çatışmasını $(\bar{x}=2,56)$ ve aile-iş temelli iş-aile çatışmasını $(\bar{x}=2,14)$ en fazla yaşayanlar $1603 \mathrm{TL}$ (asgari ücret) ve altında maaşı olanlardır. Tukey testi sonuçlarına göre; zaman temelli, gerilim temelli, davranış temelli ve aileiş temelli iş-aile çatışmasını maaşı 1603 TL ve altında olanlar(2018 yılı asgari ücreti) diğerlerine göre daha fazla yaşamaktadır. Turizm sektöründe çalışma saatlerinin yoğunluğu, fazla mesai, hafta sonu çalışmaları, çalışanlar üzerinde stres ve yorgunluk yarattığı gibi, bu çalışma karşılığında alınan ücretin yeterli olmadığı düşüncesi iş-aile çatışmasının yaşanmasındaki en büyük nedenlerden biri olabilmektedir.

Tablo $8^{\prime}$ de iş-aile çatışması alt boyutları olan zaman temelli, gerilim temelli, davranış temelli ve aile-iş temelli iş aile çatışması katılımcıların işyerinde çalışma sürelerine göre $(p<0,05)$ anlamlı bir farklılık göstermediği görülmektedir. Buna göre;

"H6. Katılımcıların yaşadıkları iş-aile çatışması, katılımcıların turizm sektöründe çalışma sürelerine göre anlamlı farklılık göstermektedir." hipotezi kabul edilmemiştir.

Turizm sektörü, yoğun iş temposuna uyum sağlamayı gerektiren, çalışma saatleri fazla olan, fiziksel ve zihinsel gücün yoğun olarak kullanıldığı, vardiyalı çalışmayı gerektiren, hizmeti sunan çalışanın sürekli iletişim halinde olmasını gerektiren bir sektördür. Tüm bu nedenler çalışan bireyleri hem fiziksel hem de zihinsel olarak yormaktadır. Dolayısıyla turizm sektöründe uzun veya kısa dönem çalışma fark etmeksizin tüm çalışanların bu nedenlere bağlı olarak iş-aile çatışması yaşadığı sonucuna ulaşılabilir. 
Tablo 8. Katılımcıların İş-Aile Çatışmasının Turizm Sektöründe Çalışma Sürelerine Göre Karşılaştırılması

\begin{tabular}{|c|c|c|c|c|c|}
\hline Boyutlar & $\begin{array}{l}\text { Turizm Sektöründe } \\
\text { Çalışma Süresi }\end{array}$ & $\mathbf{N}$ & $\bar{X}$ & Std. S. & $\mathrm{p}$ \\
\hline \multirow{8}{*}{ Zaman Temelli } & 1 yıldan az & 42 & 2,87 & 1,10 & \multirow{8}{*}{0,363} \\
\hline & 1 y1l-3 yıldan az & 42 & 3,04 & 1,10 & \\
\hline & 3 yıl-5 yıldan az & 32 & 3,03 & 1,10 & \\
\hline & 5 yıl-7 yıldan az & 18 & 2,74 & 0,92 & \\
\hline & 8 yıl-10 yıldan az & 23 & 2,74 & 1,20 & \\
\hline & 11 yıl-13 yıldan az & 4 & 1,82 & 0,89 & \\
\hline & 13 y1l-15 y1ldan az & 1 & 1,50 & - & \\
\hline & 15 yıl-17 yıldan az & 3 & 2,60 & 0,69 & \\
\hline \multirow{8}{*}{ Gerilim Temelli } & 1 yildan az & 42 & 2,47 & 1,04 & \multirow{8}{*}{0,263} \\
\hline & 1 yıl-3 yıldan az & 42 & 2,76 & 0,97 & \\
\hline & 3 y1l-5 yıldan az & 32 & 2,78 & 1,03 & \\
\hline & 5 y1l-7 yıldan az & 18 & 2,53 & 0,82 & \\
\hline & 8 yil-10 yıldan az & 23 & 2,44 & 1,11 & \\
\hline & 11 yıl-13 yıldan az & 4 & 1,73 & 0,43 & \\
\hline & 13 yıl-15 yıldan az & 1 & 1,14 & - & \\
\hline & 15 yıl-17 yıldan az & 3 & 2,28 & 0,55 & \\
\hline \multirow{8}{*}{ Davranış Temelli } & 1 yildan az & 42 & 2,20 & 1,05 & \multirow{8}{*}{0,397} \\
\hline & 1 yıl-3 yıldan az & 42 & 2,42 & 1,07 & \\
\hline & 3 y1l-5 yıldan az & 32 & 2,71 & 1,00 & \\
\hline & 5 y1l-7 yıldan az & 18 & 2,29 & 0,83 & \\
\hline & 8 y1l-10 yıldan az & 23 & 2,27 & 0,93 & \\
\hline & 11 yıl-13 yıldan az & 4 & 2,25 & 0,99 & \\
\hline & 13 yıl-15 yıldan az & 1 & 1,00 & - & \\
\hline & 15 y1l-17 yıldan az & 3 & 2,55 & 0,19 & \\
\hline \multirow{8}{*}{ Aile-İş Temelli } & 1 yildan az & 42 & 1,98 & 0,87 & \multirow{8}{*}{0,477} \\
\hline & 1 y1l-3 yıldan az & 42 & 2,21 & 1,00 & \\
\hline & 3 yil- 5 yildan az & 32 & 2,09 & 0,87 & \\
\hline & 5 y1l-7 yıldan az & 18 & 2,02 & 0,75 & \\
\hline & 8 yıl-10 yıldan az & 23 & 1,77 & 0,85 & \\
\hline & 11 yıl-13 yıldan az & 4 & 1,58 & 0,58 & \\
\hline & 13 yıl-15 yıldan az & 1 & 1,00 & - & \\
\hline & 15 yıl-17 yıldan az & 3 & 2,27 & 0,19 & \\
\hline
\end{tabular}

\section{SONUÇ VE ÖNERILER}

Bu çalışma; Malatya ilinde bulunan 3-4-5 yıldızlı konaklama işletmelerinde çalışanların iş-aile çatışmasını, iş-aile çatışmasının alt boyutları olan zaman temelli, gerilim temelli, davranış temelli ve aile-iş temelli çatışma türlerine göre ne düzeyde yaşadıklarını ölçmeye yöneliktir. İlgili literatür araştırıldığında iş-aile çatışmasına yönelik çok sayıda çalışma olsa da (Diker, 2010; Çakır, 2011; Köroğlu, 2011; Karabacak, 2013; Morkoç, 2014; Büyükyılmaz ve Akyüz, 2015; Işık, 2015; İnal, 2016; Fındık, 2016; Koç ve Kızanlıklı, 2017; Harputluoğlu ve Polat, 2017; Üzümcü ve Akpulat, 2017) Malatya ilinde böyle bir araştırmanın yapılmamış olması çalışmanın gerekliliğini ortaya koymaktadır. Malatya ilinde bulunan 3-4-5 yıldızlı konaklama işletmelerinde çalışan sayısı 264 olarak belirlenmiştir. Anket doldurmayı kabul eden otel işletmelerinin çalışan sayıları göz önüne 
alınarak 180 adet anket dağıtılmış ve bunlardan 165 tanesi doğru ve eksiksiz doldurulduğu için değerlendirilmeye alınmıştır. Elde edilen verilerin güvenirlilik ve faktör analizleri yapılmış, anket sonuçları kurulan hipotezlere göre test edilmiştir. Araştırmanın hipotezleri genel olarak konaklama işletmelerinde çalışanların demografik özelliklerine (cinsiyet, eşlerinin çalışma durumu, çocuk sahibi olmaları, gelir düzeyleri, sektörde çalışılan süre) göre iş-aile çatışmasını ne düzeyde yaşadığı ile ilgilidir.

Araştırmada otel çalışanlarının zaman temelli iş aile çatışmasını daha fazla yaşadıkları tespit edilmiştir. Katılımcılar, işlerinden dolayı ailesine fazla zaman ayıramadıklarını, iş dışındaki zamanlarının aile bireylerinin programları ve sosyal ihtiyaçlarına ayırdıkları zaman ile uyuşmadığını belirtmiştir. Buna ek olarak iş yerinde çok fazla zaman geçirdikleri için evde yeterince zaman geçiremediklerini ve çoğu zaman işlerinden dolayı aileleri ile ilgili önemli olayları kaçırdıklarını söylemiştir. Zaman temelli iş-aile çatışmasını gerilim temelli iş-aile çatışması takip etmektedir. Buna göre; katılımcıların işten eve geldiklerinde genellikle yorgun oldukları için aileleri ve arkadaşlarına eşlik edememesi gerilim kaynaklı çatışmayı ortaya çıkarmaktadır.

Turizm sektöründe çalışanların yaşadığı en büyük sıkıntılardan birinin zaman konusu olduğu yukarıda belirtilmiştir. Sektör hizmet odaklı olduğundan çalışanların iyi bir hizmet sunması için bazı durumlarda zaman açısından kendilerinden ödün vermesi gerekmektedir. Yoğun çalışma temposu, düzensiz çalışma saatleri, çalışanların kendileri ve aileleri için ayıracakları zamanları daraltmakta, kendilerini ve ailelerini olumsuz etkilemektedir. Bu durum çalışanların iş dışındaki zamanlarında gergin olmalarına ve aileleri ile sorun yaşamalarına sebep olmaktadır. Otel işletmelerinin ağır çalışma şartlarına getirilecek olan düzenlemeler hem örgütün kaliteli hizmet sunumunu doğrudan etkileyecek hem de bireyin aile ile yaşadığı (iş nedeni ile yaşanan) sorunları giderilmesinde büyük bir rol oynayacaktır

Toplum içinde kadınların çalıştıkları iş dışında, ev yaşamı ve çocuk bakımı ile ilgili sorumlulukları bulunmaktadır. Dolayısıyla iş ve aile sorumluluklarını bir arada üstlenen kadın çalışanlar erkek çalışanlara oranla daha fazla iş-aile çatışması yaşamaktadır. Bu durumun en aza indirgenmesi için evli ve özellikle çocuk sahibi olan kadınların çalışma saatlerinde işveren tarafından esneklik sağlanarak çalışan bireyin çatışma yaşaması azaltılarak çalışma verimi artırılabilir.

Araştırmaya katılan bireylerin gelir durumlarına göre tüm boyutlarda iş-aile çatışması yaşadığı saptanmıştır. Katılımcıların yaşadığı çatışma düzeyini azaltabilmek, verimliliği artırabilmek için, işverenlerin maaşın dışında performansa dayalı ek ücret verilmesi uygulamasını getirmesi hem işyeri hem de çalışan açısından motive edici olabilir. Belirlenen performansın üzerine çıkan çalışanlara ek ücretin dışında isteğe bağlı izin verilmesi de çalışanların iş-aile çatışma düzeylerinin düşürülmesine, iş yerinde verimliliğin artırılmasına katkı sağlayabilir.

\section{KAYNAKÇA}

Akpulat, A. N. ve Üzümcü, T. (2017). Turizm İşletmeleri Çalışanlarının İş-Aile Yaşam Çatışması ve Yaşam Doyumları Illişkisi: Kartepe-Çeşme Örneği, Uluslararası Sosyal Araştırmalar Dergisi, 10(51): 1070-1082.

Akyüz, S. ve Büyükyılmaz, O. (2015). Safranbolu' daki Otel ve Konak Çalışanlarının Algıladığı İşAile Yaşam Çatışmasının İş Tatmini Üzerindeki Etkisi, Akademik Bakı̧̧ Dergisi, (52): 265-284. 
Arslan, M. (2012). İş-Aile ve Aile-İş̧ Çatışmalarının Kadın Çalışanların İş Doyumları Üzerindeki Etkisi: Birey ve Toplum Dergisi, 2(3): 99-113.

Atabay, S. A. (2012). İş-Aile Çatışması ile İş Tatmini İlişkisi: Banka Çalı̧̧anları Üzerinde Bir Uygulama, Yüksek Lisans Tezi, Atatürk Üniversitesi Erzurum.

Baykal, B. (2014). Çalışma Saatleri İş-Aile Çatışması Açısından Belirleyici midir? Erkek Çalışanlar Açısından Bir İnceleme, Çalışma İlişkileri Dergisi, 5(2):10-23.

Bayraktar, E. ve Şentürk, K. F. (2018). İş-Aile Yaşam Çatışmasının Çalışanların İş ve Yaşam Tatminleri Üzerindeki Etkisi, Çalışma İlişkileri Dergisi, 9(1): 24-41.

Beutell, J. N. and Greenhaus, H. J. (1985). Sources of Conflict Between Work and Family Roles, Academy of Management, 10(1): 76-88.

Camp, S.D., Hogan, N.L., Lambert, E.G., and Ventura, L.A. (2006). The İmpact of Work-Family Conflict on Correctional Staff: A Preliminary, Criminology and Criminal Justice, 6(4): 371- 387.

Cingöz A. ve Kaya. A. (2018). İ̧̧-Aile Çatışmasının İç Girişimcilik Üzerindeki Etkisini Belirlemeye Yönelik Turizm Sektörü Çalışanları Üzerinde Bir Araştırma, Çukurova Üniversitesi İ̈BF Dergisi, 22(2):127-153.

Çakır, M. (2011). Turizm Sektöründe Işs-Aile Çatışması: Ankara'daki 4 ve 5 Yıldızlı Otel İşletmelerinde Bir Araştırma, Yüksek Lisans Tezi, Gazi Üniversitesi, Ankara.

Çarıkçı, İ. (2001). Banka Çalışanlarının İş ve Aile Rollerinin Çatışması (Bireysel ve Örgütsel Boyutlar), Doktora Tezi, Marmara Üniversitesi, İstanbul.

Diker, O. (2010). İş-Aile Çatışması ve İşe Bağlllık İlişkisinin Turizm Sektöründe İncelenmesi: Nevşehir Bölgesinde Faaliyet Gösteren Beş Yıldızlı Otel Çalı̧anları Üzerinde Bir Araştırma, Yüksek Lisans Tezi, Nevşehir Üniversitesi, Nevşehir.

Doruk, N. ve Özdevecioğlu, M. (2009). Organizasyonlarda İş-Aile ve Aile-İş Çatışmalarının Çalışanların İş ve Yaşam Tatmini Üzerindeki Etkisi, Erciyes Üniversitesi İktisadi ve İdari Bilimler Fakültesi Dergisi, (33): 69-99.

Eker, I. ve Özmete, E. (2012). İş-Aile Yaşamı Çatışması ve Roller: Kamu Sektörü Örneğinde Bir Değerlendirme, Çalışma İlişkileri Dergisi, 3(2):1-23.

Fındık, E. (2016). İş-Aile Çatışmasının Cam Tavan Sendromu Üzerindeki Etkisi: Otel İşletmelerinde Bir Araştırma, Yüksek Lisans Tez, Hacı Bektaş Veli Üniversitesi, Nevşehir.

Harputluoğlu, D. ve Polat, D. (2017). İşe Tutkunluk ve İş-Aile-İş Çatışmasının İşten Ayrılma Niyetine Etkisi: Konaklama İşletmelerinde Bir Uygulama, Sosyal Bilimler Dergisi, (13): 435-450

Işık, Z. (2015). Erzurum Palandöken Kış Turizm Merkezindeki Konaklama İşletmelerinde Çalışan Personellerde Duygusal Emek ve İş-Aile Çatışması İlişkisi, Yüksek Lisans Tezi, Atatürk Üniversitesi, Erzurum.

İnal, F. (2016), İş-Aile Çatışmasının Örgütsel Bağlılık ve İşten Ayrılma Niyeti Üzerine Etkisi, Yüksek Lisans Tezi, Hacı Bektaş Veli Üniversitesi, Nevşehir.

Karabacak, G. (2013). İş-Aile Çatışmasının İş ve Yaşam Doyumuna Etkilerinin İş Stresi ve Algılanan Sosyal Destek Açısından Otel Personeli Üzerine Bir Araştırma, Doktora Tezi, Adnan Menderes Üniversitesi, Aydın. 
Kılıç, İ. (2016). Örgütsel Güven, İş-Aile Çatışması ve İşten Ayrılma Niyeti İlişkilerinin Belirlenmesi: Seyahat Acentelerinde Bir Uygulama, Yüksek Lisans Tezi, Osmangazi Üniversitesi, Eskişehir.

Kılıç, İ., Ural, A. (2018). Bilimsel Araştırma Süreci ve Spss ile Veri Analizi. (5.Basım), Ankara: Detay Yayıncilik.

Kızanlıklı, M. ve Koç, H. (2017). İş-Aile ve Aile-İş Yaşamı Çatışması ile İş gören Performansı Arasındaki İlişki: Otel İşletmelerinde Bir Uygulama, Uluslararası İktisadi ve İdari Bilimler Dergisi, (1): 114-130.

Köroğlu, Ö. (2011). İş gören Doyumu ve Turizm İşletmelerinde Yapılan Araştırmalara İlişkin Bir Değerlendirme, ZKÜ Sosyal Bilimler Dergisi, 7(14): 246-266.

Kurtoğlu, H. (2017). Psikolojik Dayanıklılı̆̆ın İş Aile Çatışması ve İşten Ayrılma Niyetine Etkisi, Yüksek Lisans Tezi, Bahçeşehir Üniversitesi, İstanbul.

Morkoç, T. (2014). Otel Çalışanlarında Duygusal Emek ve İş-Aile Çatışması İlişkisi: İzmir Şehir Otelleri Örneği, Doktora Tezi, Dokuz Eylül Üniversitesi, İzmir.

Özen, S. ve Uzun, T. (2005). İşyerinde Çalışanın Yaşadığı Çatışmanın Azaltılmasında Örgütün ve Ailenin Rolü: Polis Memurlarına Yönelik Bir Uygulama, Dokuz Eylül Üniversitesi Sosyal Bilimler Enstitüsü Dergisi, 7(3): 128-147.

Shakhbazov, A. (2018). İş-Aile Çatışmasının İşten Ayrılma Niyeti İle İliş̧isi: Bir Alan Araştırmasıı, Yüksek Lisans Tezi, İstanbul Üniversitesi, İstanbul.

Yurtseven, Ö. (2008). İş- Aile çatışması, İş Tatmini ve İşten Ayrılma Niyeti İlişkisi: Turizm İşletmesinde Bir Uygulama, Yüksek Lisans Tezi, Akdeniz Üniversitesi, Antalya.

Yüksel, İ. (2005). İş- Aile Çatışmasının Kariyer Tatmini, İş Tatmini ve İş Davranışları ile İlişkisi, Atatürk Üniversitesi İktisadi ve İdari Bilimler Dergisi, 19(2): 301-314. 